\title{
PENGEMBANGAN LEMBAR KERJA PESERTA DIDIK (LKPD) PJOK SENAM LANTAI MERODA BERBASIS PENGUATAN PENDIDIKAN KARAKTER UNTUK PESERTA DIDIK KELAS VII SMP NEGERI 18 KOTA BENGKULU
}

\begin{tabular}{l} 
Muhammad Nuryogata \\
${ }^{123}$ Pendidikan Jasmani, FKI \\
\hline Info Artikel \\
\hline Sejarah Artikel: \\
Diterima oktober 2020 \\
Direvisi oktober 2020 \\
Diterima oktober 2020 \\
Tersedia online oktober 2020 \\
\\
Kata kunci: \\
LKPD, Penguatan Pendidikan \\
Karakter, PJOK
\end{tabular}

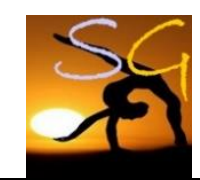

\begin{abstract}
Abstrak
Penelitian ini bertujuan mengembangkan Lembar Kerja Peserta Didik (LKPD), merupakan penelitian dan pengembangan yang biasa disebut research and development ( $R$ \& D). Subyek penelitian melibatkan peserta didik kelas VII SMP Negeri 18 Kota Bengkulu berjumlah peserta didik 27 orang dan guru dengan jumlah 2 orang. Teknik analisis data menggunakan analisis deskriptif kuantitatif yang dituangkan dalam bentuk persentase. Instrumen dan teknik pengumpulan data dengan angket. Hasil penelitian menyatakan produk yang dikembangkan layak dengan skor validasi ahli adalah, pada ahli I, aspek Kelayakan isi "sangat baik" 100\%, aspek kesesuaian dengan Pendidikan karakter "sangat baik" 97\%, aspek Didaktis "sangat baik" 93\%, aspek Konstruksi "sangat baik" $100 \%$ dan aspek Teknis "sangat baik" 93\%, sedangkan hasil akhir penilaian dilakukan ahli II aspek Kelayakan isi "sangat baik" $100 \%$, aspek Kesesuaian Pendidikan Karakter "sangat baik" 97\%, aspek Didaktis "sangat baik" 100\%,aspek Konstruksi "sangat baik" $100 \%$ dan aspek Teknis "sangat baik" 96\%. Sedangkan secara keseluruhan kualitas LKPD presentase hasil tanggapan peserta didik terhadap LKPD berbasis Pendidikan Karakter "sangat baik" dengan presentase $86 \%$ dan hasil tanggapan guru "sangat baik" dengan presentase 93\%
\end{abstract}

\section{Abstract}

Lembar Kerja Peserta Didik (LKPD), is research and development that is commonly called (R\&D). The subjects of this study were Students of grade VII of SMP Negeri 18 Bengkulu City with 27 students and 2 teachers. Data analysis techniques using quantitative descriptive analysis as outlined in the form of percentages. Data collection instruments and techniques with a questionnaire. The results of the study stated that the products developed were feasible with expert validation scores, , in expert I, Content eligibility aspects "very good" 100\%, aspects of conformity with character education "very good" 97\%, didactic 


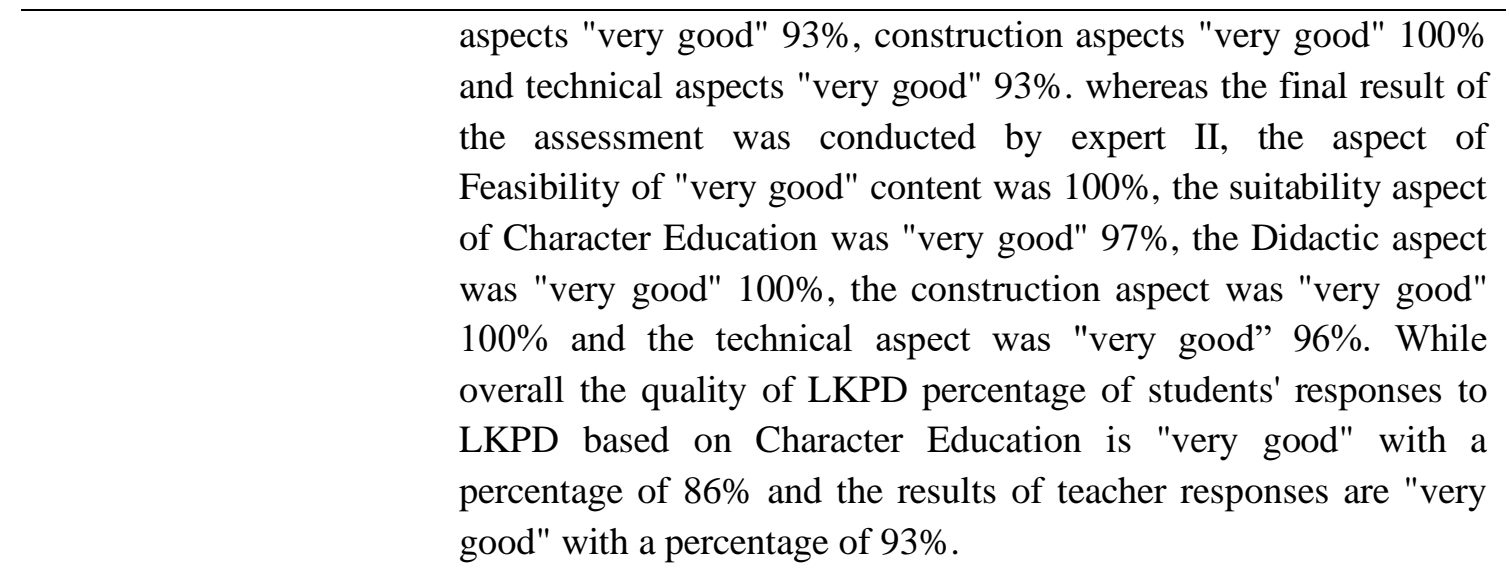

Alamat yang sesuai: Jl. Letkol Herman Haris No 18 Kota Manna

Email yang sesuai: yogatama2016@gmail.com

ISSN 2746-055X (online)

DOI : $10.33369 /$ gymnastics.v1i2.12804

\section{PENDAHULUAN}

Pendidikan adalah suatu usaha yang dilakukan secara sadar dan sengaja untuk mengubah tingkah laku manusia baik secara individu maupun kelompok untuk mendewasakan manusia melalui upaya pengajaran dan pelatihan. Pendidikan dapat mengembangkan atau meningkatkan potensi manusia melaui pengajaran dan pelatihan- pelatihan dalam proses pembelajaran sehingga mampu menghadapi setiap perubahan dari kemajuan ilmu pengetahuan dan teknologi. Dalam undang-undang no. 20 tahun 2003 tentang sistem pendidikan nasional disebutkan mengenai fungsi dan tujuan pendidikan nasional sebagai berikut: pendidikan nasional berfungsi mengembangkan kemampuan dan membentuk watak serta peradaban bangsa yang bermanfaat dalam rangka mencerdaskan kehidupan bangsa, bertujuan untuk berkembangnya potensi peserta didik agar menjadi manusia yang beriman dan bertakwa kepada tuhan yang maha esa, berakhlak mulia, sehat, berilmu, cakap, kreatif, mandiri, dan menjadi warga negara yang demokratis serta bertanggung jawab.

Makna karakter menurut kementerian pendidikan nasional (2010: 3) juga diartikan sebagai segala sesuatu yang dilakukan guru, yang mampu mempengaruhi karakter pesertadidik. Guru membantu membentuk watak peserta didik. Hal ini mencakup keteladanan bagaimana perilaku guru, caraguru berbicara atau menyampaikan materi, bagaimana guru bertoleransi, dan berbagai hal terkait lainnya.

Pendidikan karakter merupakan upaya-upaya yang dirancang dan dilaksanakan secara sistematis untuk membantu peserta didik memahami nilainilai perilaku manusia yang berhubungan dengan tuhan yang maha esa, diri sendiri, sesama manusia, lingkungan, dan kebangsaan yang terwujud dalam pikiran, sikap, perasaan, perkataan, dan perbuatan berdasarkan norma-norma agama, hukum, tata krama, budaya, dan adat istiadat 
setiap peserta didik memiliki karakterkarakter tersebut tapi hanya beberapa kartakter yang mendominasi. Mungkin metode pendidkan karakter tersebut dapat menjadi jalan menuju tercapainya tujuan pendidikan nasional. Dewasa ini kurikulum 2013 juga

Dikembangkan sebagai pedoman pelaksanaan pendidikan guna mencapai tujuan pendidikan nasional. Kurikulum 2013 yang dirancang untuk meperkuat kompetensi peserta didik dari sisi pengetahuan, keterampilan, dan sikap secara utuh.

Melihat hal tesebut, pjok yang dikenalcenderung memfokuskan pembelajarannya di ranah psikomotor juga harus memperhatikan kompetensi peserta didik di ranah kognitif. Oleh karena itu, lembar kerja peserta didik atau biasa disingkat dengan lkpd juga berperan dalam pembelajaran pjok.

Lembar kerja peserta didik merupakan salah satu komponen yang harus ada di dalam proses pembelajaran pjok, karena bahan ajar merupakan acuan guru untuk mengajarkan materi kepada siswa. Berdasarkan undang- undang sisdiknas no.20 tahun 2013 dijelaskan bahwa kewajiban guru sebelum mereka berdiri di depan kelas adalah menciptakan suasana pendidikan yang bermakna, kreatif, dinamis, dan dialogis dan mempunyai komitmen secara profesional untuk meningkatkan mutu pendidikan. Tanpa memperhatikan apakah pemerintah sudah menyediakan buku pembelajaran, buku guru, silabus, dan buku pedoman guru. Guru wajib membuat bahan ajar yang dibutuhkan oleh siswa selama bahan ajar yang disediakan oleh pemerintah tidak memenuhi harapan guru dan peserta didik. Salah satu bahan ajar yang dapat digunakan untuk membantu proses pembelajaran adalah lembar kerja peserta didik.

Berdasarkan observasi yang
dilakukan di smp negeri 18 kota
bengkulu, dalam pembelajaran pjok
adanya lkpd kurang dimanfaatkan,
dikarenakan lkpd yang ada kurang efektif
untuk pembelajaran pjok. Dan saat
melakukan magang di smp negeri 18
bengkulu sangat sedikit pembelajaran
yang memasukkan pendidikan karakter
didalam nya.

Hasil wawancara dengan beberapa peserta didik kelas vii juga menyatakan bahwa pemanfaatan lkpd belum dapat mengoptimalakan potensi siswa dalam memahami pelajaran. Selain itu, pembelajaran dalam lkpd tersebut juga kurang bervariasi, hanya berisi materi dan latihan soal. Oleh karena itu, lkpd yang

Dikembangkan berdasarkan karakter dalam diri peserta didik mungkin dapat menjadi salah satu solusi. Tidak hanya itu, lkpd yang dapat menciptakan pembelajaran yang lebih bermakna, menyenangkan dan dapat meningkatkan pemahaman peserta didik juga menjadi harapan. Namun pada kenyataannya pendidik lebih memilih untuk tidak menggunakan lkpd daripada mengembangkan lkpd yang berakibat 
kurangnya kompetensi peserta didik dalam aspek kognitif.

Dalam permendikbud no. 24 tahun 2016 lampiran 22 tentang kompetensi inti (ki) dan kompetensi dasar (kd) pendidikan jasmani, olahraga dan kesehatan untuk smp/mts menyebutkan kompetensi dasar untuk smp/mts poin 3.9 yaitu "memahami perkembangan tubuh remaja yang meliputi perubahan fisik sekunder dan mental", berdasarkan hal tersebut telah ditentukan materi yang akan dikembangkan yaitu "senam lantai meroda" yang dipelajari oleh peserta didik kelas vii smp. Peneliti memilih materi senam karena materi tersebut dianggap sangat penting untuk diketahui peserta didik yang menginjak usia remaja. Dalam materi tersebut berisi tentang bagaimana ciri perkembangan, bagaimana mengatasi masalah gerak pada masa remaja, bagaimana kehidupan sosial remaja, bagaimana hidup sehat bagi remaja dan lain- lain. Dengan mengatahui tentang materi senam maka peserta didik tahu bagaimana harus bersikap dan menghadapi permasalahan yang mungkin akan mucul selama mempelajari aktivitas gerak.

Berdasarkan uraian yang telah disampaikan di atas, peneliti akan melakukan penelitian terhadap pengembangan lembar kerja peserta didik (lkpd) berbasis pemuatan pendidikan karakterpada materi senam dengan judul "pengembangan lembar kerja peserta didik (lkpd) pjok senam lantai meroda berbasis penguatan pendidikan karakter untuk peserta didik kelas vii smp negeri 18 kota bengkulu".

\section{METODE}

Penelitian ini menggunakan penelitian dan pengembangan atau biasa dikenal dengan research and development ( $\mathrm{r} \& \mathrm{~d}$ ). Metode penelitian dan pengembangan adalah metode penelitian yang digunakan untuk menghasilkan produk tertentu, dan Menguji keefektifan produk tersebut (sugiyono, 2011).

Penelitian dan pengembangan adalah konsep yang relative masih baru dalam bidang pendidikan. Ilmu pengetahuan dapat dianggap sebagai strategi mencari pengetahuan yang kurang lebih bersifat abstrak yang dinakan teori. Sugiyono (2013:297) menyatakan metode penelitian dan pengembangan adalah metode penelitian yang digunakan untuk menghasilkan produk tertentu, dan menguji keefektifan produk tersebut. Untuk dapat menghasilkan produk tertentu digunakan penelitian yang bersifat analisis kebutuhan dan untuk menguji keefektifan produk tersebut supaya dapat berfungsi di masyarakat luas, maka diperlukan penelitian untuk menguji keefektifan produk tersebut. Jadi penelitian dan pengembangan bersifat longitudinal.

Penelitian dan pengembangan berbeda dengan penelitian biasa yang hanya menghasilkan saran bagi perbaikan, penelitian dan pengembangan menghasilkan produk yang langsung digunakan. Metode pengembangan ini 
telah banyak digunakan pada bidang ilmu pengetahuan dan teknik.

Subyek penelitian ini adalah peserta didik kelas vii smp negeri 18 kota bengkulu. Uji coba produk dilaksanakan dengan 27 peserta didik dan 2 guru olahraga. Metode pengumpulan data yang digunakan untuk mendapatkan data adalah sebagai berikut :

\section{Metode Angket (Kuesioner)}

Metode ini merupakan teknik pengumpulan data yang dilakukan dengan cara memberi seperangkat pertanyaan atau pernyataan tertulis kepada responden untuk dijawabnya (sugiyono 2013:142). Dalam penelitian ini metode angket digunakan untuk mengetahui kelayakan lkpd yang telah dikembangkan. Hal ini bertujuan untuk memperoleh hasil penelitian kelayakan lkpd untuk diterapkan pada pembelajaran. Peneliti menggunakan skala likert dengan 5 alternatif jawaban untuk menghitung skor pada masing-masing jawaban.

Angket Validasi

Angket validasi digunakan untuk menganalisis kelayakan lkpd oleh pakar berupa pengembangan instrumen penilaian Kelayakan isi, penyajian dan bahasa. Dalam penelitian ini memodifikasi angket dari penelitian yang diakukan riosha yunita devi dengan judul penelitian pengembangan lembar kerja peserta didik (lkpd) pjok berbasis multiple intelligences pada materi perkembangan tubuh remaja untuk peserta didik kelas vii smp negeri 1 banguntapan

Angket Tanggapan

1) Angket Tanggapan Siswa

Angket ini digunakan untuk mengetahui tanggapan siswaterhadap lkpd yang dikembangkan.

\section{2) Angket Tanggapan Guru}

Angket tanggapan guru diberikan dengan tujuan untuk mengetahui seberapa layak dan menarik lkpd yang dikembangkan dalam membantu guru menyampaikan materi pada kegiatan pembelajaran.

Untuk mengetahui hasil penelitian yang dilakukan maka harus dilakukan analisis data. Teknik analisa data yang dilakukan pada penelitian ini adalah teknik analisa kuantitatif yang bersifat penilaian menggunakan angka. Menurut suharsimi arikunto dalam faris insani (2016) data yang bersifat kuantitatif yang berwujud angka-angka hasil perhitungan atau pengukuran dapat diproses dengan menjumlahkan, membandingkan, dengan jumlah yang diharapkan sehingga diperoleh persentase. Rumus yang digunakan yaitu : (anas sudijono, 2006 :43) dengan Rumus $\mathbf{P}=\frac{\boldsymbol{f}}{\boldsymbol{n}} \mathbf{1 0 0}$ dengan $\mathrm{p}$ adalah presentase, $\mathrm{f}$ adalah skor yang dipilih, dan $\mathrm{n}$ adalah skor maksimal.

\section{HASIL DAN PEMBAHASAN PENELITIAN}

Deskripsi produk

Produk yang dikembangkan dalam bentuk lkpd. Produk awal yang 
dihasilkan dinamakan "lkpd senam lantai meroda berbasis penguatan pendidikan karakter" untuk memberikan wawasan seputar materi senam lantai meroda. Produk lkpd ini dikembangkan dengan konsep teori penguatan pendidikan karakter.

\section{Hasil penelitian}

Hasil penelitian pengembangan berupa lkpd pjok berbasis penguatan pendidikan karakter yang diterapkan pada materi senam lantai meroda ini meliputi (1) deskripsi penelitian (2) hasil pengembangan $1 \mathrm{kpd}$ berbasis penguatan pendidikan. Karakter (3) hasil penelitian dan kelayakan lkpd.

\section{Analisis data}

Berdasarkan data yang diperoleh dalam penelitian ini, analisis data dilakukan secara cermat dan teliti dengan analisa data yang diperoleh menghasilkan beberapa hal sebagi berikut :

1. Setelah dilakukan beberapa tahap validasi ahli dan revisi, produk ini dinyatakan "sangat baik" dan diijinkan untuk melakukan uji coba.

2. Berdasarkan tes uji coba menunjukkan hasil kategori "sangat baik" pada tanggapan peserta didik dan guru pjok. Hasil data yang diperoleh diinterpretasikan menurut kategori yang telah ditentukan.

\section{Pembahasan}

Pada awal pengembangan lkpd ini didesain dan diproduksi menjadi sebuah produk awal berupa lkpd untuk peserta didik. Proses pengembangan melalui prosedur penelitian dan pengembangan. Kemudian produkdikembangkan menggunakan microsoftword dan canva. Setelah produk awal dihasilkan maka perlu dievaluasi kepada para ahli melalui validasi ahli dan perlu di ujicobakan kepada peserta didik. Tahap evaluasi dilakukan pada ahli. Sedangkan tahap penelitian dilakukan dengan uji coba kepada peserta didik dan guru.

Proses validasi ahli dilkakukan menggunakan tiga tahap. Tahap pertama masih dalam kategori baik sehingga banyak masukan dari ahli untuk perbaikan lkpd. Data validasi tahap i dijadikan dasar untuk merevisi produk, setelah revisi yang pertama produk divalidasi lagi hingga siap digunakan untuk uji coba.

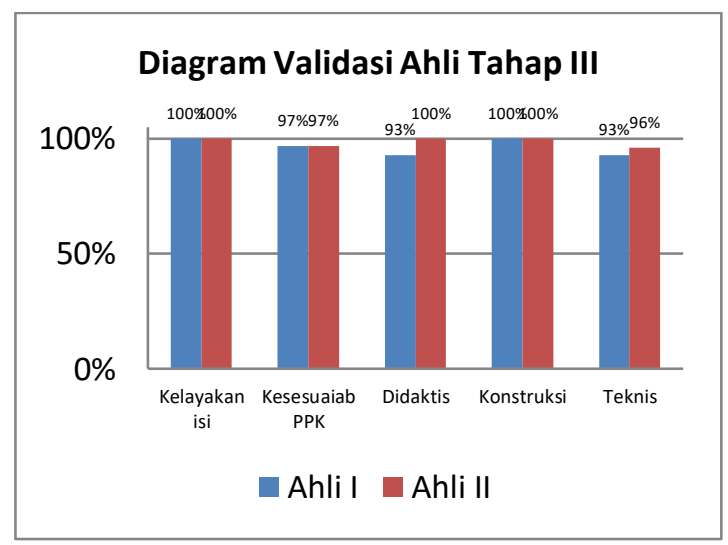

Gambar 1. Hasil Validasi Tahap III

Pada diagram batang tersebut memiliki hasil penilaian "sangat baik" kehadiran lkpd mendapat sambutan yang baik dan bias digunakan. Para peserta didik dan guru pjok menyarankan agar produk tersebut dicetak lebih banyak dan bias diedarkan ke masyarakat luas 


\section{PENUTUP}

\section{Simpulan}

Berdasarkan hasil penelitian dapat disimpulkan bahwa lembar kerja peserta didik (lpkd) pjok dengan mengintegralkan 5 pendidikan karakter, meliputi:

Kualitas penilaian presentase akhir lkpd kedua ahli adalah, pada ahli i, aspek kelayakan isi "sangat baik" 100\%, aspek kesesuaian dengan pendidikan karakter sangat baik" 97\%, aspek didaktis "sangat Baik" 93\%, aspek konstruksi "sangat baik" 100\% dan aspek teknis "sangat baik" 93\%, sedangkan hasil akhir penilaian dilakukan ahli ii aspek kelayakan isi "sangat baik" 100\%, aspek kesesuaian pendidikan karakter "sangat baik" 97\%, aspek didaktis "sangat baik" 100\%,aspek konstruksi "sangat baik" $100 \%$ dan aspek teknis "sangat baik" 96\%. Sedangkan secara keseluruhan kualitas lkpd presentase hasil tanggapan peserta didik terhadap lkpd berbasis pendidikan karakter "sangat baik" dengan presentase $86 \%$ dan hasil tanggapan guru "sangat baik" dengan presentase $93 \%$.

\section{Implikasi hasil penelitian}

Implikasi penelitian yang berjudul pengembangan lkpd pjok senam lantai meroda berbasis penguatan pendidikan karakter untuk peserta didik kelas vii smp negeri 18 kota bengkulu adalah:

1. Produk lkpd pjok berbasis penguatan pendidikan karakter ini dapat digunakan dalam pembelajaran sehingga dapat menambah pengetahuan peserta didik
2. Produk $1 \mathrm{kpd}$ pjok berbasis penguatan pendidikan karakter ini dapat digunakan sebagai sumber belajar peserta didik secara mandiri maupun kelompok

3. Lkpd ini dapat mempermudah dan membantu guru pjok dalam proses pembelajaran

\section{Saran}

1. Sebelum menyusun lkpd, sebaiknya kita mengetahui perbedaan kepribadian dan karakter pada peserta didik.

2. Lkpd ini dapat digunakan sebagai bahan ajar pelengkap dalam pembelajaran pjok.

3. Lkpd yang dikembangkan dapat menjadi referensi untuk pengembangan lkpd pada materi lain dengan berbasis pada pendidikan karakter peserta didik.

\section{DAFTAR PUSTAKA}

Akmal, A., Sugihartono, T., \& Ilahi, B. R. (2018). ANALISIS MUATAN MATERI SENAM PADA BAHAN AJAR PJOK SEKOLAH DASAR NEGERI DI KOTA BENGKULU. Kinestetik: Jurnal Ilmiah Pendidikan Jasmani, 2(1), 11-15.

Arikunto, S. (2012). Dasar-Dasar Evaluasi Pendidikan. Jakarta: Bumiaksara.

Canggih, H. M., \& Sugihartono, T. (2018). PERBEDAAN HASIL LATIHAN SENAM POCO-POCO OLAHRAGA MENGGUNAKAN METODE KONVENSIONAL DAN INSTRUKSIONAL SISWA LAKI- 
LAKI DAN PEREMPUAN DI SDN 75 KOTA BENGKULU. Kinestetik: Jurnal Ilmiah Pendidikan Jasmani, 2(2), 202214.

Dalton,Willian \& Hari Amirullah Rachman.(2014). Modifikasi Model Pembelajaran Sport Education Berbasis Kejuaraan Untuk Guru Pjok Smp. Jurnal Keolahragaan. No 1 Vol 2.

Depdiknas, U. U. R. I. N., \& No, R. I. (2003). Tentang Sistem Pendidikan Nasional. Jakarta: Depdiknas.

Depdiknas.(2006).

Panduan

Pengembangan Bahan Ajar. Jakarta: Direktorat Pembinaan Sekolah Menengah Atas.

Depdiknas, (2008). Pengembangan Bahan Ajar Dan Media. Jakarta: Departemen Pendidikan Nasional

Desmita.(2009). Psikologi Perkembangan Peserta Didik. Bandung : Pt Remaja Rosda Karya

Fajrida, Yunila. (2015) Lembar Kerja Peserta Didik (Lkpd). Diakses Di Http://Yafajridabiologiuir.Blogspot. Co.Id/2 015/11/Lembaran-KerjaPeserta-Didik-Lkpd.Html . Pada Tanggal 28 Januari 2020

Hidayat, Sholeh.(2013). Pengembangan Kurikulum Baru. Bandung : $\mathrm{Pt}$ Rosda Karya

Husdarta H.J.S. (2013). Model Pembelajaran Langsung Dalam
Pendidikan Jasmani Dan

Kesehatan. Bandung : Alfabeta

Jean, Peaget. (2006). Teori Perkembangan Kognitif.

Yogyakarta : Kanisius

Khan, Yahya. (2010). Pendidikan Karakter Berbasis Potensi Diri. Jakarta : Pelangipublishing

Mutohir Cholik (1992). Uu Sistem Keolahragaan Nasional, Penerbit: Sunda Kelapa Pustaka

Muhajir. (2016). Pendidikan Jasmani, Olahraga Dan Kesehatan. Jakarta : Kemendikbud

Prastowo, Andi. (2011). Metode Penelitian Kualitatif Dalam Perspektif Rancangan Penelitian. Jakarta : Ar-Ruzz Media

Rohaeti, E., Lfx, E. W., \& Padmaningrum, R.T. (2009). Pengembangan Lembar Kerja Siswa (Lks) Mata Pelajaran Sains Kimia Untuk Smp. Jurnal Inovasi Pendidikan, 10(1).

S. Nasution. (2003). Berbagai Pendekatan Dalam Proses Belajar \& Mengajar. Jakarta: Bumi Aksara

Saptono. (2011). Dimensi-Dimensi Pendidikan Karakter. Jakarta : Erlangga

Sari, Y., \& Pujianto, D. (2018). Pengaruh Metode Bermain Terhadap Hasil Belajar Senam Lantai Roll Belakang Pada Siswa Kelas Viii 
Smp Negeri 4 Bengkulu. Kinestetik: Jurnal Ilmiah Pendidikan Jasmani, 2(1), 75-80.

Sudjijono. (2006).Pengantar Statistik Pendidikan.Jakarta : Pt Raja Grafindo Persada

Sugihartono, T., Sutisyana, A., \& Sugiyanto, S. (2020). Produktivitas Lembar Kerja Peserta Didik (Lkpd) Pjok Dengan Penerapan Model Projek Base Learning Pada Prodi Penjas Fkip Unib. Kinestetik: Jurnal Ilmiah Pendidikan Jasmani, 4(1), 63-72.

Sugiyono. (2013). Metode Penelitian Kuantitatif Kualitatif Dan R \& D. Bandung : Alfabeta

Sukintaka. (2004). Teori Pendidikan Jasmani.

Utama, Bandi. (2011). Pembentukan Karakter Anak Melalui Aktivitas Bermain Dalam Pendidikan Jasmani. Jurnal Pendidikan Jasmani Indonesia. No 1 Vol 8. Hlm 2

Widjajanti, Endang. (2008). Pelatihan Penyusunan Lks Mata Pelajaran Kimia Berdasarkan Kurikulum Tingkat Satuan Pendidikan Bagi Guru Smk/Mak. Makalah. Yogyakarta: Fmipa Uny.

Wijayanti, Frieda. (2014). Pengembangan Lks Ipa Berbasis Multiple Intelligence Pada Tema Energi Dan Kesehatan Untuk Meningkatkan Kemampuan Berpikir Kreatif
Siswa. Skripsi Fmipa Unnes : Tidak Diterbitkan

Zuriah, Nurul. (2007). Pendidikan Moral Dan Budi Pekerti Dalam Perspektif Perubahan. Jakarta : bumi aksara 